Rajaa T Sulieman

BDS, MSc (Assis. Lect.)

\section{The Antibacterial Effect of Myrtus Communis as Root Canal Irrigant: A comparative Study}

\author{
Department of Conservative Dentistry \\ College of Dentistry, University of Mosul
}

\begin{abstract}
Aims: To evaluate the antibacterial effect of Myrtus communis alcoholic extract solution when used as intracanal irrigant and to compare it with the currently used root canal irrigants. Materials and methods: Samples of 30 patients of both sexes were included in the in vitro study having 30 uniradicular necrotic pulp. Microbiological samples were obtained from the root canal and then transferred for laboratory work. In the clinical trail "in vivo", samples of 32 patients having uniradicular necrotic pulp. They were randomly divided into four groups major depending on the type of irrigant solution used. Samples from root canal obtained at the beginning of the study and after treatment. The percentage of the reduction of the counts for both aerobic and anaerobic bacteria were calculated. Results: The in vitro study showed that the minimum inhibitory concentration (MIC) was obtained with the $35 \%$ Myrtus communis alcoholic extract. In the clinical trail, the antimicrobial effectiveness of 35\% Myrtus communis alcoholic extract solution was evident and comparable with that from other commonly used root canal irrigant like chlorhexidine $0.2 \%$ and sodium hypochlorite $5.25 \%$. Conclusions: This study revealed that alcoholic extraction solution (35\%) from Myrtus communis has antibacterial effect and could be used as root canal irrigant.
\end{abstract}

Key words: Antibacterial effect, Myrtus communis, root canal irrigant.

Suliman RT. The Antibacterial Effect of Myrtus communis as Root Canal Irrigant: A comparative Study. Al-Rafidain Dent J. 2009; 9 (2): 289-296.

Received: 29/4/2008 Sent to Referees: 30/4/2008 Accepted for Publication: 2/9/2008

\section{INTRODUCTION}

The aim of endodontic therapy is to remove pathogenic bacteria from the pulp system $^{(1)}$. Following thorough instrumentation of an infected root canal, there will be significant reduced number of bacteria, but it is well documented that instrumentation alone can not clean all the internal surface of the root canal and bacteria can be found on the root canal walls, within the dentinal tubules and in the lateral canals ${ }^{(2)}$. Antibacterial irrigants and the interappointment intracanal medicaments are needed to kill the remaining microorganisms ${ }^{(2)}$.

The irrigant solutions are very important during root canal preparation, because they aid in the cleaning of the root canal, lubricate the files, flush out debris, having antimicrobial effect and tissue dissolution without damage periapical tissues, as well as, some of them have bleaching effect ${ }^{(3)}$.

Sterile normal saline is the most biocompatible irrigant solution, because it is inactive with minimum effect on the periapical tissue ${ }^{(4)}$.

Chlorhexidine gluconate has a wide spectrum of antimicrobial activity, it is a unique in its ability to bind to oral tissue for extended periods from which it is released slowly and relatively non-toxic ${ }^{(5)}$.

Sodium hypochlorite has proven to be an effective solution for the chemomechanical preparation of root canal because of its antimicrobial activity and tissue dissolving ability ${ }^{(6)}$.

Myrtle (Myrtus communis), have been shown to possess antibacterial activity against both gram-positive and gramnegative organisms. Gram - positive organisms were found to be the most sensitive particularly Bacillus sabtilis and Micrococcus glutamious. In vitro antiviral activity against influenza type $\mathrm{A}$ has been documented $^{(7)}$. Myrtus communis extraction solution have antiseptic activities when used as a mouth wash. No major side effects or complains following the use of plants extract rinses were reported by the patients ${ }^{(8)}$.

The aim of this study to evaluate the antibacterial effect of Myrtus communis alcoholic extract solution when used as intracanal irrigant and to compare it with the currently used root canal irrigants. 


\section{MATERIALS AND METHODS}

1.Patient Selection: This study was carried out at the College of Dentistry, University of Mosul. The study was divided into two parts. The in vitro study; included 30 patients of both sexes, all having uniradicular necrotic pulp. In the second part, clinical study in vivo was conducted on 32 patients also having uniradicular necrotic pulp. The age range were from 18-40 years in both study groups. Samples taken from uniradicular necrotic pulp which was determined by radiographic presence of apical rarefaction and lack of response to pulp vitality test by using electric pulp tester.

2.Chemical Preparation of Myrtus communis: Alcoholic extraction solution was prepared. The procedure including using of 200 grams (powder) from leaves of Myrtus communis dissolved with one liter of $70 \%$ ethanol. The solution left for 24 hours then filtered by Number 1 filter paper, and filterate was autoclaved at $40^{\circ} \mathrm{C}$ for 3 hours ${ }^{(9)}$. The final volume of the solution become 70 $\mathrm{ml}$ and the concentration of the solution was equal to $140 \%(\mathrm{~W} / \mathrm{V})(1.4 \mathrm{~g} / \mathrm{ml})$. Then five dilutions were prepared from this stock solution (100\%, 70\%, 50\%, 35\% and 25\%).

3.Microbiological Examination: Microbiological samples were obtained from the root canal at the first appointment. At the beginning of the first appointment, the tooth was isolated with rubber dam. The tooth surrounding and the clamp were disinfected with $70 \%$ ethanol alcohol. An access opening was made with a sterile bur at high speed. Sterile absorbent paper points soak previously in normal saline were prepared, the two paper points one after one was inserted into the root canals to the apical foramen and left for one minute after determination of the canal length by placing sterile No.10 or $15 \mathrm{~K}$ type file inside the canal. A radiograph was taken and file length adjusted within $1 \mathrm{~mm}$ of radiographic apex ${ }^{(10)}$.

With a sterile dental tweezers, the paper points were removed from the root canal, one of the paper point was placed in the screw capped vial containing $5 \mathrm{ml}$ of thioglycollate broth for anaerobic bacteria, and the other paper point was placed in another screw capped vial containing $5 \mathrm{ml}$ of brain heart infusion broth for aerobic bacteria. The samples were then trans- ferred for incubation at $37^{\circ} \mathrm{C}$ for 18 hours $^{(10)}$.

Evaluation of antibacterial effect of alcoholic extract of Myrtus communis using the stock solution and the five dilutions were determined using broth microdilution method for aerobic and anaerobic bacteria $^{(11,12)}$.

In the clinical trail, samples from 32 patients were included in the study. Their age range from 18 - 40 years. The patients divided into 4 groups depending on the root canal irrigation solution used during treatment of necrotic tooth:

Group I: Irrigation with 35\% Myrtus communis alcoholic extract solution.

Group II: Irrigation with $0.2 \%$ chlorhexidine gluconate solution.

Group III: Irrigation with 5.25 \% sodium hypochlorite.

Group IV: Irrigation with normal saline.

The microbiological samples obtained from the root canal as follows:

1. At the beginning of the first appointment.

2. At the beginning of the second appointment.

3. At the end of the second appointment.

4. At the beginning of the third appointment.

At the beginning of the first appointment, microbiological samples were obtained from the root canals. Instrumentation and irrigatin of the root canals followed by good dryness for the root canals, application of intracanal medicament, temporary dressing for the tooth. The samples were then transferred for microbiological study.

At the beginning of the second appointment (2-3) days later, the tooth was isolated, the temporary dressing was removed and microbiological samples of the root canal contents were taken and complete process of instrumentation and irrigation, at the end of second appointment another microbiological sample was taken.

The same procedure was done at the beginning of the third appointment (2-3) days later.

The microbiological study was done in the Microbiology Laboratory, Department of Dental Basic Sciences, College of Dentistry, University of Mosul. 
The data were tabulated according to the number of bacterial colonies counts on each culture media. The mean and standard deviation for both aerobic and anaerobic bacteria at different appointments were calculated and the percentages of reduction were calculated also. The analysis of variance at level of significance $(p<$ 0.01 ) and Duncan New Multiple Range Test at level of significance $(p<0.05)$ were performed to compare between groups.

\section{RESULTS}

In vitro study, the antibacterial effect of alcoholic extract of Myrtus communis against aerobic microorganisms was compared with commonly used root canal irrigants. The analysis of variance at level of significant $(p<0.01)$ was performed. The results reveal that all different concentrations of Myrtus communis (140\%, 100\%, $70 \%, 50 \%, 35 \%, 25 \%)$, $5.25 \%$ sodium hypochlorite and $0.2 \%$ chlorhexidine had antibacterial effect significantly different from normal saline and the later failed to show any significant effect, 35\% Myrtus communis alcoholic extract has the best antibacterial activity when compared with other dilutions. $140 \%$ had antimicrobial effect similar to $100 \%$, however $70 \%$ had antimicrobial effect nearly similar to $50 \%$ but $25 \%$ showed high antimicrobial effect than that of $140 \%, 100 \%, 70 \%$ and $50 \%$ which were significantly different. This was shown in Table (1) and Figure (1).

Results also showed that $0.2 \%$ chlorhexidine had antibacterial effect nearly similar to $35 \%$ Myrtus communis alcoholic extract. Sodium hypochlorite at $5.25 \%$ concentration had a highest antimicrobial effect among used root canal irrigants. This was shown in Table (1) and Figure (1).

Table (1): Duncan's Multiple Range Test for in vitro antibacterial effect of Myrtus communis extraction solution and root canal irrigants against aerobic microorganisms.

\begin{tabular}{ccc}
\hline Examined solutions & $\begin{array}{c}\text { Absorbance } \\
\text { Mean }(\mathbf{n m}) \pm \text { SD }\end{array}$ & Duncan's grouping \\
\hline Control +ve Aerobic microorgamisms & $0.908 \pm 0.158$ & $\mathrm{~A}$ \\
Normal saline & $0.808 \pm 0.074$ & $\mathrm{AB}$ \\
Chlorhexidine 0.2\% & $0.206 \pm 0.053$ & $\mathrm{~F}$ \\
Sodium hypochlorite 5.25\% & $0.180 \pm 0.07$ & $\mathrm{~F}$ \\
Myrtus communis 140\% & $0.538 \pm 0.094$ & $\mathrm{C}$ \\
Myrtus communis 100\% & $0.518 \pm 0.06$ & $\mathrm{C}$ \\
Myrtus communis 70\% & $0.467 \pm 0.075$ & $\mathrm{CD}$ \\
Myrtus communis 50\% & $0.406 \pm 0.06$ & $\mathrm{D}$ \\
Myrtus communis 35\% & $0.256 \pm 0.07$ & $\mathrm{EF}$ \\
Myrtus communis 25\% & $0.290 \pm 0.05$ & $\mathrm{E}$ \\
\hline
\end{tabular}

The different letters means significant difference exists.

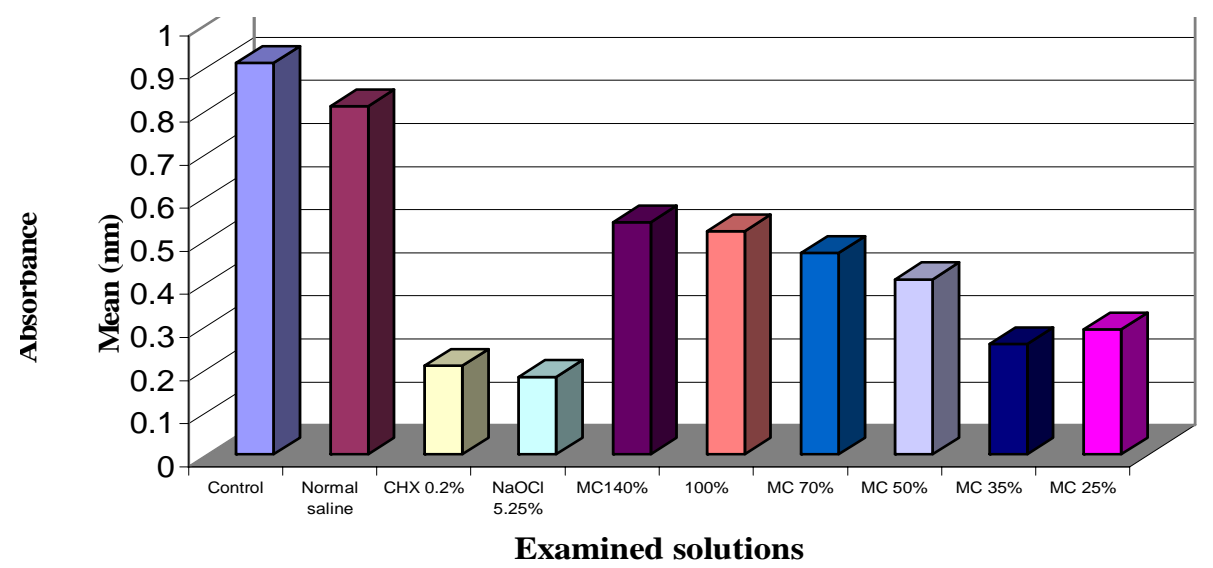

CHX: Chlorhexidine, NaOCl: sodium hypochlorite, MC: Myrtus communis.

Figure (1): Histogram showed the in vitro antibacterial effect of Myrtus communis extraction solution and root canal irrigants against aerobic microorganisms. 
Similar results were obtained with anaerobic microorganisms and shown in Ta- ble (2) and Figure (2). So 35\% dilution was selected to be used in the clinical trail.

Table (2): Duncan's Multiple Range Test for in vitro antibacterial effect of Myrtus communis extraction solution and root canal irrigants against anaerobic microorganisms.

\begin{tabular}{ccc}
\hline Examined solutions & $\begin{array}{c}\text { Absorbance } \\
\text { Mean (nm) } \pm \text { SD }\end{array}$ & $\begin{array}{c}\text { Duncan's } \\
\text { grouping }\end{array}$ \\
\hline Control +ve Aerobic microorgamisms & $1.101 \pm 0.154$ & $\mathrm{~A}$ \\
Normal saline & $0.810 \pm 0.06$ & $\mathrm{AB}$ \\
Chlorhexidine 0.2\% & $0.211 \pm 0.07$ & $\mathrm{~F}$ \\
Sodium hypochlorite 5.25\% & $0.190 \pm 0.07$ & $\mathrm{~F}$ \\
Myrtus communis 140\% & $0.530 \pm 0.08$ & $\mathrm{C}$ \\
Myrtus communis 100\% & $0.521 \pm 0.05$ & $\mathrm{C}$ \\
Myrtus communis 70\% & $0.480 \pm 0.07$ & $\mathrm{CD}$ \\
Myrtus communis 50\% & $0.410 \pm 0.05$ & $\mathrm{D}$ \\
Myrtus communis 35\% & $0.260 \pm 0.06$ & $\mathrm{EF}$ \\
Myrtus communis 25\% & $0.310 \pm 0.06$ & $\mathrm{E}$ \\
\hline
\end{tabular}

The different letters means significant difference exists.

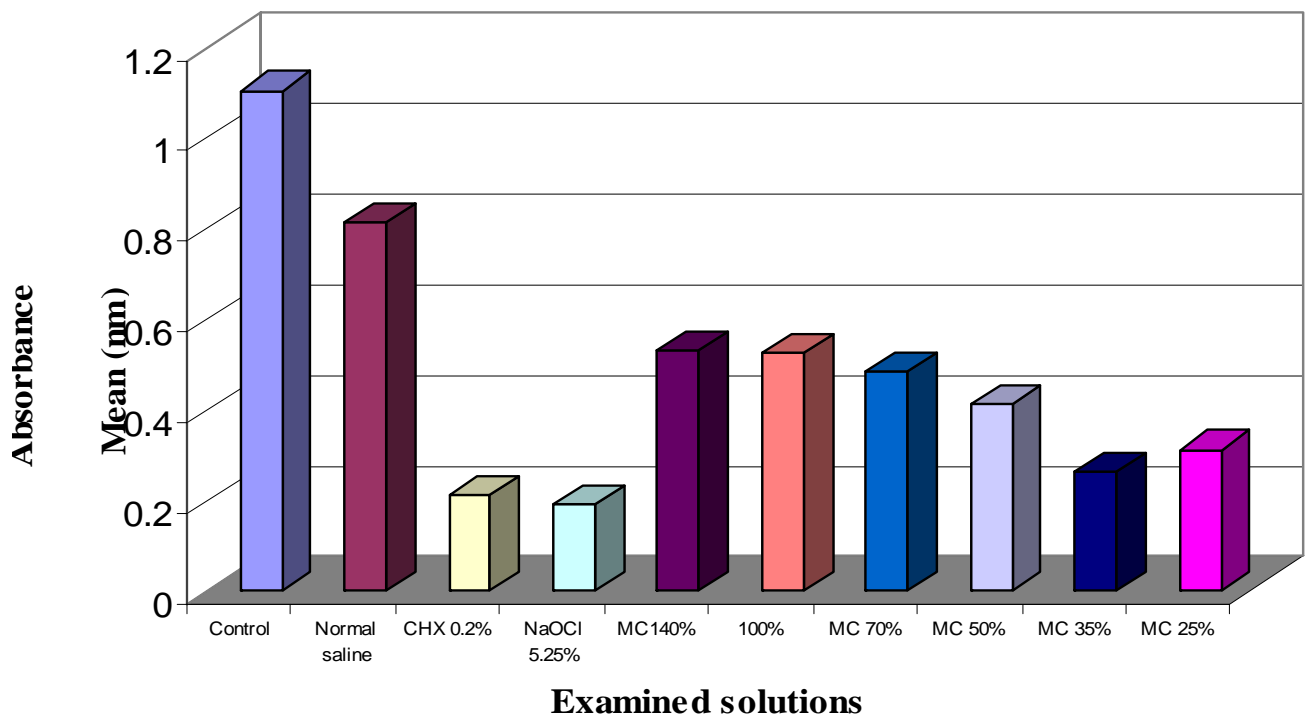

CHX: Chlorhexidine, NaOCl: sodium hypochlorite, MC: Myrtus communis.

Figure (2): Histogram shows the in vitro antibacterial effect of Myrtus communis extraction solution and root canal irrigants against anaerobic microorganisms.

In vivo study showed that the percentage of reduction for the aerobic bacterial count, at the beginning of the second appointment; at the end of second appointment and at the beginning of the third appointment for group I was 32\%, 98.72\% and $98.5 \%$ respectively, for group II was $33.7 \%$, 98.83\% and $98.63 \%$ respectively, for group III was 39.3\%. $99.32 \%$ and $99.03 \%$ respectively and for group IV was $10.7 \%, 70.8 \%$ and $48.6 \%$ respectively Table (3). 
Table (3): The changes and percentages of reduction of the count of aerobic bacteria from first appointment for four groups.

\begin{tabular}{|c|c|c|c|c|c|}
\hline \multirow[t]{2}{*}{ Groups } & \multicolumn{4}{|c|}{$\begin{array}{c}\text { Mean } \pm \text { SD } \\
\% \\
\text { Appointment number } \\
\end{array}$} & \multirow[t]{2}{*}{$\begin{array}{c}P- \\
\text { Value* }\end{array}$} \\
\hline & First & Second* & Second $* *$ & Third & \\
\hline $\begin{array}{l}\text { Group I } \\
\text { (35\%) Myrtus } \\
\text { communis }\end{array}$ & $1020 \pm 166.1$ & $\begin{array}{c}690 \pm 159.4 \\
(32 \%)\end{array}$ & $\begin{array}{l}13.1 \pm 1.9 \\
(98.72 \%)\end{array}$ & $\begin{array}{l}15.9 \pm 2.1 \\
(98.5 \%)\end{array}$ & $<0.05$ \\
\hline $\begin{array}{l}\text { Group II } \\
(0.2 \%) \text { Chlor- } \\
\text { hexidine }\end{array}$ & $1030 \pm 180.6$ & $\begin{array}{c}683.0 \pm 160.1 \\
(33.7 \%)\end{array}$ & $\begin{array}{l}12.1 \pm 2.2 \\
(98.83 \%)\end{array}$ & $\begin{array}{l}14.2 \pm 2.3 \\
(98.63 \%)\end{array}$ & $<0.05$ \\
\hline $\begin{array}{l}\text { Group III } \\
\text { (5.25\%) Sodium } \\
\text { hypochlorite }\end{array}$ & $1035 \pm 190.3$ & $\begin{array}{c}630 \pm 213.8 \\
(39.2 \%)\end{array}$ & $\begin{array}{c}7.2 \pm 1.9 \\
(99.32 \%)\end{array}$ & $\begin{array}{l}10.1 \pm 1.5 \\
(99.03 \%)\end{array}$ & $<0.05$ \\
\hline $\begin{array}{l}\text { Group IV } \\
\text { Normal saline }\end{array}$ & $1030 \pm 251.3$ & $\begin{array}{c}920 \pm 292.3 \\
(10.7 \%)\end{array}$ & $\begin{array}{c}301.1 \pm 50.6 \\
(70.8 \%) \\
\end{array}$ & $\begin{array}{c}501.2 \pm 61.7 \\
(48.6 \%) \\
\end{array}$ & $<0.05$ \\
\hline
\end{tabular}

*Beginning of the second appointment;** End of the second appointment; Data are presented mean \pm SD, (\%); P-Value* < 0.05: significant effect.

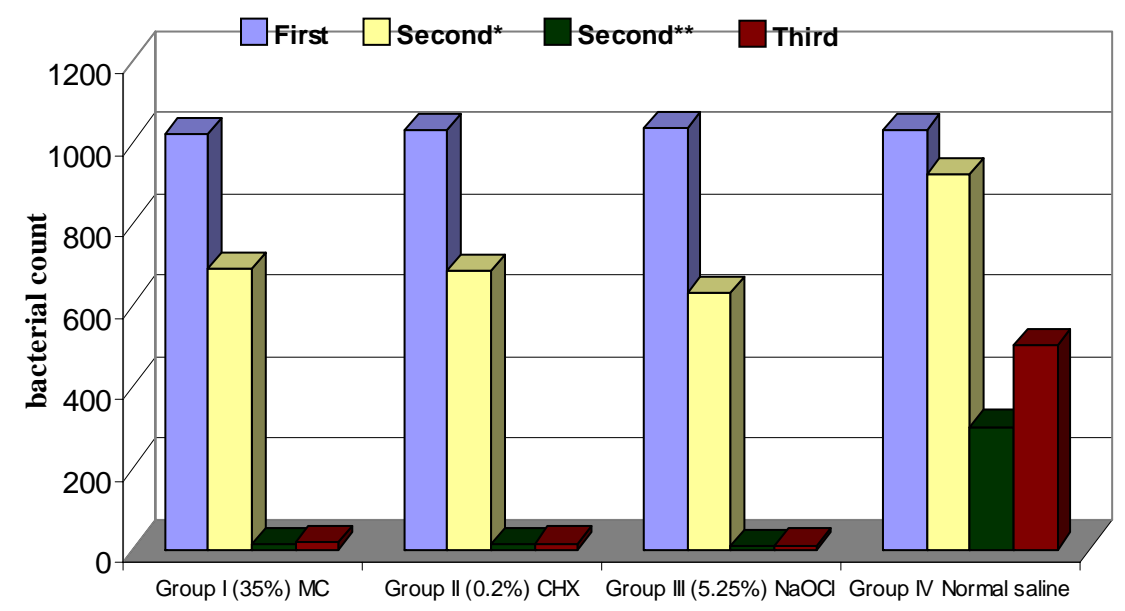

MC: Myrtus communis. CHX: Chlorhexidine, $\mathrm{NaOCl}$ : sodium hypochlorite.

Figure (3): Histogram shows the reduction of the count of aerobic bacteria from first appointment for four groups.

The percentage of reduction for the anaerobic bacterial count, at the beginning of the second appointment; at the end of second appointment and at the beginning of the third appointment for group I was $30.2 \%$, $98.63 \%$ and $98.55 \%$ respectively, for group II was $32.6 \%, 98.77 \%$ and $98.68 \%$ respectively, for group III was 36.3\%. $99.28 \%$ and $99.04 \%$ respectively and for group IV was $9.9 \%, 68.5 \%$ and $47.3 \%$ respectively, Table (4).

Comparing the results at different appointments among the four groups, it was found that the mean bacterial counts (both aerobic and anaerobic bacteria) at the beginning of the first appointment was significantly not different ( $p>0.01$ ), for all groups. But the mean bacterial counts at the beginning of the second appointment, at the end of second appointment and at the beginning of the third appointment, for group I statistically had significant difference $(p<0.05)$ from group IV, but statistically had no significant difference ( $p>$ 0.05 ) from group II and III. 
Table (4): The changes percentages of reduction of the count of anaerobic bacteria from first appointment for four groups.

\begin{tabular}{|c|c|c|c|c|c|}
\hline \multirow[t]{2}{*}{ Groups } & \multicolumn{4}{|c|}{$\begin{array}{c}\text { Mean } \pm \text { SD } \\
\% \\
\text { Appointment number }\end{array}$} & \multirow[t]{2}{*}{$\begin{array}{c}P \text { - } \\
\text { Value* }\end{array}$} \\
\hline & First & Second* & Second ** & Third & \\
\hline $\begin{array}{c}\text { Group I } \\
\text { (35\%) Myrtus } \\
\text { communis }\end{array}$ & $1103 \pm 160.2$ & $\begin{array}{c}770 \pm 150.2 \\
(30.2 \%)\end{array}$ & $\begin{array}{l}215.2 \pm 1.3 \\
(98.63 \%)\end{array}$ & $\begin{array}{l}16.1 \pm 1.9 \\
(98.55 \%)\end{array}$ & $<0.05$ \\
\hline $\begin{array}{l}\text { Group II } \\
\text { (0.2\%) Chlor- } \\
\text { hexidine }\end{array}$ & $1122 \pm 157.1$ & $\begin{array}{c}757.153 .2 \\
(32.6 \%)\end{array}$ & $\begin{array}{l}13.9 \pm 2.7 \\
(98.77 \%)\end{array}$ & $\begin{array}{l}14.9 \pm 2.6 \\
(98.68 \%)\end{array}$ & $<0.05$ \\
\hline $\begin{array}{l}\text { Group III } \\
\text { (5.25\%) Sodium } \\
\text { hypochlorite }\end{array}$ & $1130 \pm 160.1$ & $\begin{array}{c}720 \pm 150.1 \\
(36.3 \%)\end{array}$ & $\begin{array}{c}8.2 \pm 2.1 \\
(99.28 \%)\end{array}$ & $\begin{array}{l}10.9 \pm 1.2 \\
(99.04 \%)\end{array}$ & $<0.05$ \\
\hline $\begin{array}{c}\text { Group IV } \\
\text { Normal saline }\end{array}$ & $1122 \pm 230$ & $\begin{array}{c}1010 \pm 270 \\
(9.9 \%)\end{array}$ & $\begin{array}{c}353.4 \pm 48.6 \\
(68.5 \%)\end{array}$ & $\begin{array}{c}591 \pm 60.1 \\
(47.3 \%)\end{array}$ & $<0.05$ \\
\hline
\end{tabular}

*Beginning of the second appointment; ** End of the second appointment; Data are presented mean \pm SD, (\%); P-Value* < 0.05: significant effect.

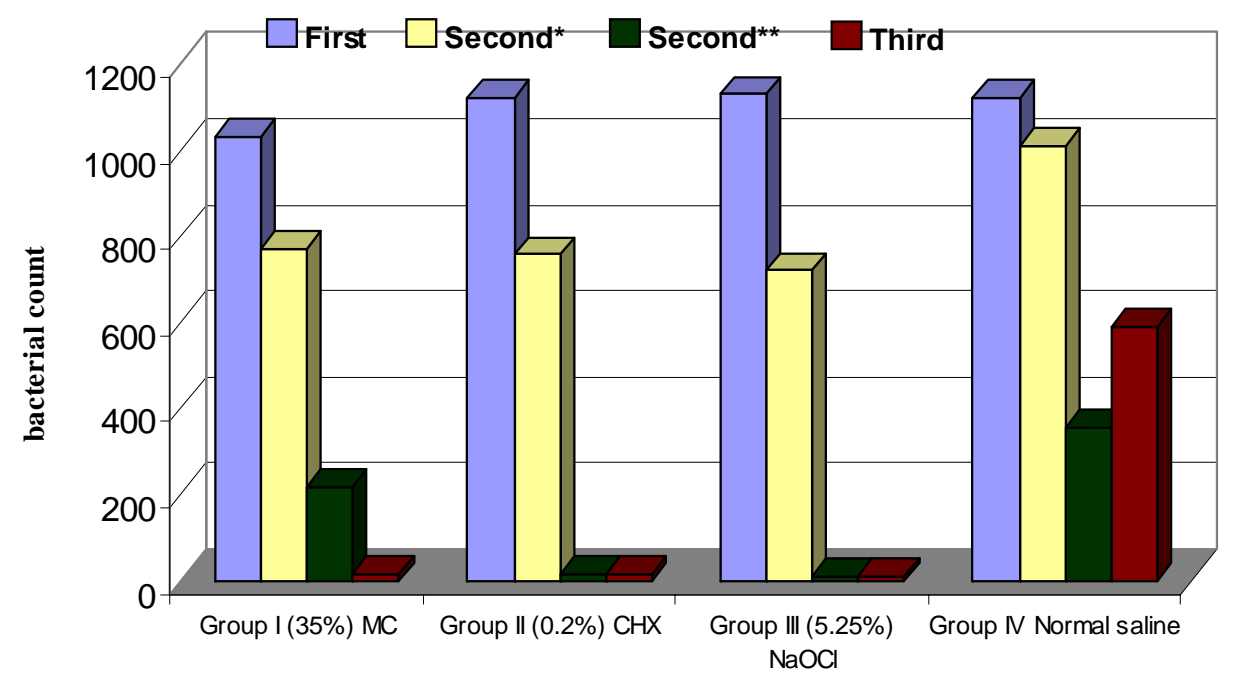

MC: Myrtus communis. CHX: Chlorhexidine, NaOCl: sodium hypochlorite,

Figure (4): Histogram shows the reduction of the count of anaerobic bacteria from first appointment for four groups.

\section{DISCUSSION}

The results of the study indicated that alcoholic extract of Myrtus communis showed antimicrobial effect when used as root canal irrigant at different dilutions, but the best antibacterial effect was noticed at dilution of $35 \%$. This can be explained by the fact that Myrtus communis contain poly - phenolic and tannic compounds in their structures ${ }^{(8)}$.

The poly phenolic and tannic compounds are defined as compounds having molecular weight between 500 -3000 and besides giving usual phenolic reaction they have special properties such as the ability to precipitate the gelatin and other proteins.
The total extract of Myrtus communis leaves has antimicrobial activity due to the presence of polyphenoles ${ }^{(8)}$. Also tannic acid extracted has the greatest inhibitory effect on the proteolytic activities of Prophyromonas gingivalis, Bacteriodes intermedius and Troponema denticola ${ }^{(13,14)}$.

Myrtus communis leaves extract contain compounds which have promising benefits in the treatment of some infections diseases and suppress the growth of Candida albicans, Candida lipolica, Proteus vulgaris, Staphylococcus aureus ${ }^{(15)}$.

From an economical point of view, the extract products of plants are considered 
as extracts with a commercial value, when the extract products weight more than $5 \mathrm{~g}$ for each $200 \mathrm{~g}$ of plant dried powder used in extraction procedures ${ }^{(14)}$.

Alcoholic extraction has the ability to dissolve the active ingredients of Myrtus communis which makes the alcoholic extract of plants more potent than the boiling water extract $^{(14)}$.

Also the alcoholic extracts of plant appear to have as much wider margin of safety than that of the boiling water extracts ${ }^{(15)}$.

Chlorhexidine solution has a broad spectrum antimicrobial activity against a wide range of gram positive and gram negative bacteria, yeast, fungi, facultative anaerobes and aerobes. Therefore, it is used during the endodontic treatment as root canal irrigant $(14,16)$

Clinical and laboratory studies showed that $5.25 \%$ solution of sodium hypochlorite will destroy most microorganisms found in the root canal system therefore sodium hypochlorite remains as the irrigant of choice in root canal therapy ${ }^{(17)}$.

\section{CONCLUSIONS}

Under the conditions of this study alcoholic extractions from Myrtus communis showed; that $35 \%$ was the best concentration used as root canal irrigant due to antibacterial effect. Moderate dilution for the extracted solution make it more flowable and resorbable. It was comparable to $5.25 \%$ sodium hypochlorite and $0.2 \%$ chlorhexidine solution and showed nearly similar effect.

This finding is rather expected because plants contains polyphenolic and tannis compounds.

\section{REFERENCES}

1.Saleh IM, Rytler LE, Haapasalo D. Survivalof Enterococcus feacalis in infected dentinal tubules after root canal filling with different root canal sealers: in vitro study. $J$. Endod. 2004; 37: 193 - 198.

2. Meneze M M, Valera M C, Jorge AO, Kogacy camargo $\mathrm{CH}$, Mancini $\mathrm{MN}$. In vitro Evaluation the Effectiveness of Irrigants and Intracanal Medicament. Int Endod J. 2004; 37 (5): 311- 319.

3.Estrela C, Estrela CRA, Pecora JD. A study of the time necessary for calcium hydroxide to eliminate microorganisms in the infected canal. J App Oral Sc. 2003; 11: 133 $-137$.

4.Griffiths BM, Stock CR. The efficiency of irrigants in the removing root canal debris when used with an ultrasonic preparation technique. Int. Endod. 1986; 19_ 277.

5.Jeansonne MJ, White RR. A comparison of $2 \%$ chlorhexidine gluconate and 5.25\% sodium hypochlorite as antimicrobial endodontic irrigants. J Endod. 1994; 20: 276.

6.Emboava JC, Luiz E, Dementino T, Fernando L. Solvent action of sodium hypochlorite on bovine pulp and physiochemical properties of resulting liquid. Braz Dent J. 2001; 1: 154-157.

7.Joanne B, Linda A. and David P.J. Eucalyptus, herbal medicines, 2nd edition.LA and Phillipson DJ by Pharmacentical Press.h.k. 2002.

8. Al - Rawi A, Chayravarty HL. Qurencus inferctoria, Myrtus communis: In medical plants of Iraq. Al-Hauria House Press, Baghdad. 1988. Pp. 67 - 88.

9. Al -Jeboory A. Ethnopharmacology. AlHauria House Press, Baghdad. 1994. Pp. $83-74$.

10. Abdal AK, Habib HM, Talab AM. Bacteriological status of the root canal of the teeth in Mosul and Vicinty. Iraq Med. J. 1987; 35: 67 - 70 .

11. Abdul - Rahman GHY, Khalaf SH. The use of some medicinal plants in dental caries prevention. Al-Rafidain J. Sci. 2002; 13:1.

12. Estrela CRA, Estrela C, Reis C, Bammann LL, Pecro JD. Control of microorganism in vitro by endodontic irrigants. Braz. Dent. J. 2003; 14: 1 - 8.

13. Homer KA, Manji F, Beighton D. Inhibitory of peptidase and glycosidase activities of Porphyromonas gingivalis, Bacteriodes intermedius and Treponema deticola by plant extracts. J Clin Periodontol. 1992: $305-310$.

14. Al - Naimi WH. The effect of washes extracted from Myrtus communis and Qurencus infectroia on dental plaque formation. M.Sc. Thesis, University of Baghdad, Iraq. 1995.

15. Abdul Latif MJ, AlZohyri AM, AlJeboory A. Cardiovascular and antimicrobial effects of Myrtus communis. $J$ Biolog Scien Res. 1988; 19: 307 - 317. 
16. Sessone LM, fidel RAS, Dias M. Antimicrobial activity of different concentration of $\mathrm{NaOCl}$ and chlorhexidine. Braz Dent $J$. 2003; 14: 1-7.
17. Siqueira JF. Strategies to treat infected root canals. J. Calif. Dent. Assoc.; 2001; 25: 14-19. 